\title{
Performance of male and female girolando calves in gradual weaning with sorghum silage supplementation
}

\begin{abstract}
This study aimed to evaluate the solid food intake, performance and diarrhea incidence male and female Girolando young calves. The following fractional artificial milk feeding was used: from the 3 rd to the 33 rd day received 3liters of milk in the morning and 3liters in the afternoon, only in the morning the calves received 3liters from the 34 th to 49 thdays, and 2 liters between 50th to 63thdays. All calves were provided ad libitum access to water and for starter concentrate and sorghum silage, from the 2th and 4th weeks, respectively. The animals were evaluated in subdivided plot design, comparing female males during nine weeks of live. We observed higher body weight and weight gain for females compared to males from 6th and 7th weeds, respectively $(p<0.05)$. The concentrate intake was significantly higher for males from 5 th week, while silage intake was higher for females from 6 th week $(\mathrm{p}<0.05)$. Diarrhea index was low in female and negatively correlated with weight gain, body weight and wither and croup height $(\mathrm{p}<0.001)$. Specifically for males, this index correlated positively with the starter concentrate intake of from 5 th week $(p<0.05)$. In conclusion, females presented better performance ingesting more silage than male calves. Starter concentrate intake was higher for males which could be considered a risk for rumen acidosis and diarrhea.
\end{abstract}

Keywords: dairy cattle, girolando, weight gain, ponderal development, diarrhea, semiarid
Volume 5 Issue 5 - 2017

\author{
lara Maria França Reis, Kariny Fonseca da \\ Silva, Matheus Xavier Costa, Pedro Augusto \\ Motta Moreira Ribeiro, Emanuelly Gomes \\ Alves Mariano, Brenda Karoline Alcântara \\ Faria, Mário Henrique França Mourthé, \\ Luciana Castro Geraseev and Eduardo \\ Robson Duarte \\ Universidade Federal de Minas Gerais, Brazil
}

Correspondence: Eduardo Robson Duarte, Instituto de Ciências Agrárias, Universidade Federal de Minas Gerais, Av Universitária 1000, Bairro Universitário, Montes Claros, MG, 39400-006, Brasil, Tel +55 382101 7707, Fax +55 382101 7703, Email duartevet@hotmail.com

Received: April 08, 2017| Published: August 21, 2017
Abbreviations: BW, body weight; ADF, detergent acid fiber; DM, dry mater; NDF, neutral detergent fiber; WG, weight gain

\section{Introduction}

Calves raised separately from their dam and submitted to transition from milk liquid feed to solid feed (grains and or forage) has been the principal management to minimizing losses related with diseases, increasing daily weight gains and reducing costs with the supply of milk. ${ }^{1}$ However this system has been reported frequently to Bos taurus races and little is known about artificial milk supplementation to Zebu race or to hybrids as Girolando. The breeding of Girolando male calves has economic interest because these calves can be intended for the beef production in pasture systems after weaning. ${ }^{2}$ Conventional technique provides limited supply of milk (about $10 \%$ of $\mathrm{BW} / \mathrm{d}$ ) to calves encouraging starter intake and promoting early rumen development and weaning. However, studies have shown the feeding higher amounts of milk enhances growth rates, improves feed efficiency, ${ }^{3}$ decreases the occurrence of diseases ${ }^{4}$ and behavioral signs of hunger. ${ }^{5}$ Increased milk intake decreases starter intake of, and this lag in the initiation of solid feed intake could delay rumen development and reduce growth at weaning. ${ }^{6}$

Gradual weaning of high milk-fed calves can increase solid feed consumption to maintain better BW gain during and after weaning. ${ }^{7}$ Introducing forage during the milk feeding period has long been discouraged, as the forage is thought to displace concentrate intake. ${ }^{8}$ Forage shows less energy dense than calf starter feed, so inclusion of forage in the diets during the pre-weaning period results in poorer body weight (bw) gains in calves fed restricted and low quantities of milk. ${ }^{9}$ However, previous studies have assessed the effects of forage on calves fed milk at approximately 4 to $5 \mathrm{~L} / \mathrm{d}$ (about $10 \%$ of calf birth weight). New research reported that provision forage to calves fed high volumes of milk promoted increasing of solid feed dry mater (dm) intake and rumen development without reduction of bw gain. ${ }^{10} \mathrm{In}$ tropical regions the main forage available to dairy cattle has been corn or sorghum silage that has high levels of energy. Often hay production is laborious in dairy farms and many producers have starting supplying silage to calves before weaning. In our knowledge the performance of these animals has not been investigated with the inclusion of these silages in the initial calf breeding stage. Additionally, little is known about the performance between male and female Girolando calves raised under this management.

\section{Materials and methods}

The experiment was conducted at the Dairy Cattle Sector of the Instituto of Ciências Agrárias of the Universidade Federal of Minas Gerais in Montes Claros - MG, located at $16.686316^{\circ}$ south latitude, $43.843763^{\circ}$ longitude east of Greenwich and has 646 meters of altitude. The climate of the region is classified as tropical humid, with dry summer (As) according to the classification of Köppen, ${ }^{11}$ is marked by a dry season from May to September and a period of rains of January and February. The averagemonthly precipitation and temperatures during the dry season are, respectively, $14.1 \mathrm{~mm}$ and $23.2^{\circ} \mathrm{C}$.

The procedures adopted in this study were approved by the ethics committee for the use of animals CEUA UFMG, under protocol number 128/2013. A total of 30 calves, (12) male and (18) female, 
$1 / 2$ or $3 / 4$ Holandês $x$ Gir calves were allocated to individual houses equipped with buckets for administration of concentrate, silage, milk and water. After birth, the animals were fed colostrums from their mothers for threedays and the navel was cleaned with $10 \%$ iodine solution. At birth and every sevendays the animals were weighed and measured, the height of the croup and the withers and the thorax circumference. Milk from the herd was supplied in two meals (morning and afternoon) in plastic buckets, and $50 \%$ of the total amount was administered at each meal. The following fractional artificial feeding was used: from the 3 rd to the 33 rd day of experimentation received 3 liters of milk in the morning and 3liters in the afternoon, only in the morning the calves received 3liters from the 34 th to the $49^{\text {th }}$ days, and 2 liters between 50 th to 63 th days.

The milk used was analyzed in the Laboratory of Milk Analysis of Veterinary School of UFMG, Belo Horizonte, Minas Gerais, Brazil. The average composition was $3.0 \%$ crude protein, $4.7 \%$ fat, $4.4 \%$ lactose and $12.0 \%$ total solids. According to Silva \& Queiroz ${ }^{12}$ the analysis of the sorghum silage showed $33.05 \%$ dry matter (dm), crude protein $(6.08 \%$ of the $\mathrm{dm})$, mineral matter $(6.22 \%$ of the $\mathrm{dm})$ and NDF ( $64.25 \%$ of the $\mathrm{dm}$ ) and ADF (35.8 of the $\mathrm{dm}$ ). This silage was daily inspected for possible contamination with mold or putrefaction. The calves received ad libitum a starter concentrate for dairy calves (Lacmaster ${ }^{\circledR}$ ) and sorghum silage, from the second and fourth weeks of experimentation, respectively. For the calculation of the supply of these foods was adopted $10 \%$ of surplus of the previous day. After the storage of weekly samples, a total sample pool was used to determine: dry matter, mineral matter, crude protein, neutral detergent fiber, acid detergent fiber, ethereal extract according to the methodologies described by Silva \& Queiroz. ${ }^{12}$

The starter concentrate represented a mix of soybean, soybean shell, ground whole corn, wheat bran mesh, minerals and vitamins and presented the following levels of guarantee $/ \mathrm{kg}$ dry matter: humidity(maxim) 70.00g; crude fiber(max) 42.50g; ADF(max) 70.00g; ethereal extract(minim) 29.00g; mineral matter(max) 86.00g; crude protein(min) $200.00 \mathrm{~g}$; calcium(min) $11.50 \mathrm{~g}$; phosphorus(min) 4,329g; sodium(min) 2,180g; sulfur(min) 1.,737.00mg; chrome(min) 0.80mg; cobalt(min) $14.00 \mathrm{mg}$; copper(min) $22.00 \mathrm{mg}$; iodine(min) $1.00 \mathrm{mg}$; manganese $(\mathrm{min}) 78.00 \mathrm{mg}$; selenium $(\mathrm{min}) 0.37 \mathrm{mg}$; iron $(\mathrm{min})$ $52.00 \mathrm{mg}$; monensin sodium $(\mathrm{min}) 64.00 \mathrm{mg}$; zinc $(\mathrm{min}) 92.00 \mathrm{mg}$; vitamin A(min) 14,800iu; vitamin D3(min) 4800iu; vitamin E(min) 40.00iu; mannan $(\mathrm{min}) 280.00 \mathrm{mg}$. Starter and silage intakes were obtained by difference between the quantity supplied and the leftovers of the day. The weekly consumption was evaluated considering the daily averages of in natura consumption of concentrate and sorghum silage. For the analysis of the weekly diarrhea index, the means of daily fecal consistency were evaluated according to the scores proposed by Lucci (13), where feces were considered normal (1.0), firm but not hard, with a shape distorted when falling floor; mole (2.0) without evident form, they spread on the ground although they accumulate in mounds; stream (3.0) spreads rapidly, they do not form mounds, but there is some consistency; aqueous (4.0) where they are expelled in jets, without consistency, aspect of water.

The calves were visually observed daily for any sign of illness (nasal discharge, cough, and diarrhea). The calves remained healthy and exhibited no signs of illness during the experiment except mild diarrhea. The animals were evaluated in subdivided plot design, comparing female males during nine weeks of live. The data of daily weight gain (wg), body weight (bw) and silage and starter concentrate intakes were evaluated in variance analysis and the means compared by the Scott-Knott or the student $\mathrm{T}$ tests. The diarrhea index was evaluated by non-parametric Kruskal-Wallis or Wilconxon tests. These variables, along with the body measurements were also analyzed based on the Pearson Correlation coefficients. Analyzes were processed in the statistical package SAEG.9.0, considering the significance of $5 \%$.

\section{Results}

In this study, the birth weight did not vary between males (39.65 \pm 0.51$)$ and females $(39.72 \pm 1.43)$, however the bw and wg were higher for females than males from Sixth and seventh weeks, respectively $(p<0.05$, Table 1$)$. The concentrate intake was significantly higher for males from week 5 , while silage intake was higher for females from week $6(\mathrm{p}<0.05$, Table 1$)$. In this research, we observed higher bw and wg for females compared to males from 42 and 49 days of life, respectively ( $<<0.05$, Table 1$)$. The concentrate intake was significantly higher for males from 35 days of age, while silage consumption was higher for females from 42days of age $(\mathrm{p}<0.05$, Table 1). For females, the increase in wg correlated positively with croup height, thoracic circumference, and concentrate and silage intakes $(\mathrm{p}<0.001)$ and was negatively correlated with diarrhea index $(p<0.05)$. The increase in the wg of the male calves was positively correlated with the rump and wither heights, thoracic circumference, and concentrate and silage intake $(p<0.001)$. Concentration and silage intakes correlated positively with rump and wither heights and thoracic circumference $(\mathrm{p}<0.001)$. Diarrhea index was negatively correlated with wg, bw, height of withers and croup $(p<0.001)$. Specifically for males, this index correlated positively with the starter intake from $5^{\text {th }}$ week of age $(p<0.05)$. For both sexes the increase in bw was significantly correlated to silage and starter concentrate intakes ( $p<0.001$, Pearson Coefficient $>0.90$ ).

Table I Performance and consumption means of concentrate and sorghum silage for male and female Girolando calves in fractionated artificial feeding system

\begin{tabular}{|c|c|c|c|c|c|c|c|c|c|c|}
\hline \multirow{2}{*}{ Genders } & \multicolumn{9}{|c|}{ Calf Ages (weeks) } & \multirow{2}{*}{ CV \% } \\
\hline & $\mathbf{I}$ & 2 & 3 & 4 & 5 & 6 & 7 & 8 & 9 & \\
\hline \multicolumn{11}{|c|}{ Weight gain (Kg) } \\
\hline Females & $0 \mathrm{C}$ & $3.01 \mathrm{~B}$ & $4.18 \mathrm{~B}$ & $2.87 \mathrm{~B}$ & $4.47 \mathrm{~B}$ & $4.77 \mathrm{~B}$ & $5.16 \mathrm{Ba}$ & $6.06 \mathrm{Aa}$ & $4.52 \mathrm{Ba}$ & $55.45^{*}$ \\
\hline Males & $O B$ & $2.15 \mathrm{~B}$ & $2.34 \mathrm{~B}$ & $2.58 \mathrm{~B}$ & $2.40 \mathrm{~B}$ & $4.59 \mathrm{~A}$ & $3.35 \mathrm{Ab}$ & $5.09 \mathrm{Ab}$ & $3.53 \mathrm{Ab}$ & \\
\hline \multicolumn{11}{|c|}{ Body weight (Kg) } \\
\hline Females & $40.1 \mathrm{Ja}$ & $42.55 \mathrm{la}$ & $46.73 \mathrm{Ha}$ & $49.01 \mathrm{Ga}$ & $53.66 \mathrm{Fa}$ & $58.43 \mathrm{Ea}$ & 63.59 Da & $69.66 \mathrm{Ca}$ & 74. $19 \mathrm{Ba}$ & 4.16 \\
\hline Males & $39.6 \mathrm{Ha}$ & $4 I .8 I \mathrm{Ga}$ & $44.15 \mathrm{Ga}$ & $46.74 \mathrm{Fa}$ & 48.97Ea & $53.56 \mathrm{Db}$ & $56.91 \mathrm{Cb}$ & $62.00 \mathrm{Bb}$ & $65.11 \mathrm{Ab}$ & \\
\hline \multicolumn{11}{|c|}{ Average of starter concentrate intakes ( $\mathrm{g}$ of dry matter) } \\
\hline Female & $0 \mathrm{G}$ & $\mathrm{II}, \mathrm{I} 8 \mathrm{Ga}$ & $51,59 \mathrm{Ga}$ & $108,15 \mathrm{Fa}$ & $\begin{array}{l}235,19 \\
E b\end{array}$ & $356,84 \mathrm{Db}$ & $516,44 \mathrm{Cb}$ & $588,20 \mathrm{Bb}$ & $696,0 \mathrm{Ab}$ & 15.19 \\
\hline
\end{tabular}


Table Continued...

\begin{tabular}{|c|c|c|c|c|c|c|c|c|c|c|}
\hline \multirow{2}{*}{ Genders } & \multicolumn{9}{|c|}{ Calf Ages (weeks) } & \multirow{2}{*}{ CV \% } \\
\hline & I & 2 & 3 & 4 & 5 & 6 & 7 & 8 & 9 & \\
\hline \multicolumn{11}{|c|}{ Average of starter concentrate intakes ( $g$ of dry matter) } \\
\hline Males & 이 & $17.63 \mathrm{Ha}$ & $54.94 \mathrm{Ga}$ & 135.9Fa & $4 \mid 4.0 \mathrm{Ea}$ & $571.9 \mathrm{Da}$ & $758.37 \mathrm{Ca}$ & $868.75 \mathrm{Ba}$ & $969.73 \mathrm{Aa}$ & \\
\hline \multicolumn{11}{|c|}{ Average of silage intakes ( $g$ of dry matter) } \\
\hline Female & $0 \mathrm{~F}$ & $0 \mathrm{~F}$ & $0 \mathrm{~F}$ & $O F$ & $30.77 \mathrm{Fa}$ & $280.33 \mathrm{Ea}$ & $\begin{array}{l}579.46 \\
\mathrm{Da}\end{array}$ & $877.34 \mathrm{Ca}$ & $991.83 \mathrm{Ba}$ & 12.3 \\
\hline Males & $0 \mathrm{~F}$ & $0 \mathrm{~F}$ & $0 \mathrm{~F}$ & $0 \mathrm{~F}$ & $45.47 \mathrm{Ea}$ & 206.28Db & $572.13 \mathrm{Cb}$ & $743.29 \mathrm{Bb}$ & $762.86 \mathrm{Ab}$ & \\
\hline \multicolumn{11}{|c|}{ Average of diarrhea index* } \\
\hline Female & $1.0 \mathrm{Ab}$ & $1.005 \mathrm{~A}$ & $1.0 \mathrm{~A}$ & $\mathrm{I} .0 \mathrm{~A}$ & $\mathrm{I} .0 \mathrm{~A}$ & $1.0 \mathrm{~A}$ & $1.0 \mathrm{Ab}$ & $1.0 \mathrm{~A}$ & $\mathrm{I} .0 \mathrm{~A}$ & 50.36 \\
\hline Males & I.IAa & $1.0 \mathrm{~B}$ & $1.0 \mathrm{~B}$ & $1.0 \mathrm{~B}$ & $\mathrm{I} .0 \mathrm{~B}$ & $1.0 \mathrm{~B}$ & I.IAa & $1.0 \mathrm{~B}$ & $\mathrm{I} .0 \mathrm{~B}$ & \\
\hline
\end{tabular}

$C V$, coefficient of variation; *Data analyzed in non-parametric tests of kruskal wallis or wilconxon ( $<<0.05 \%)$. Different lowercase letters in the columns and uppercase lines differ significantly by the scott-knott test $(p<0.05)$

\section{Discussion}

In this study, the birth weights of both male and female animals did not differ. However Oliveira \& Nogueira ${ }^{2}$ reported that females were significantly lighter than males. These differences could be justified by the racial composition of the mother cows, which in this study were represented predominantly by Holstein cows with higher bw. The mean weight gains obtained for the 63days of live $(0.547 \pm 0.070$ for females and $0.414 \pm 0.032$ for males) are efficient considering that the animals almost doubled birth weight. This performance in artificial feeding with supplementation of sorghum silage and concentrate, observed in this research, was superior to that reported in natural suckling for Girolando calves described by Oliveira \& Nogueira. ${ }^{2}$ These authors verified bw of 63.0 and $60.0 \mathrm{~kg}$ for males and females at 90days, respectively, whereas in this present study at 63 days of age the bw were 74.18 and $65.79 \mathrm{~kg}$ for females and males, respectively.

The intake of sorghum silage and the wg of the females were higher than the males from the sixth and seventh weeks of life, respectively. This best performance for Girolando female calves was also reported by Oliveira \& Nogueira ${ }^{2}$ and could represent a genetic characteristic of these animals, which should be elucidated in future studies. In this research another factor that could contribute to justify these differences could be related to the higher intake of concentrate for male than female calves from the fifth week, presenting the average intake of $937.0 \mathrm{~g}$ of concentrate per day in the last week before weaning. Thus, this high consumption could favor the occurrence of sub-acute acidosis in the ruminal environment in formation and contributing to the occurrence of diarrhea. However, future studies should better elucidate these changes in these animals. Special care in the proposed management should be employed, limiting the intake of concentrates mainly to male calves to avoid metabolic disturbances and compromise the colonization of cellulolytic microorganisms in the rumen, which should be investigated in future studies. The fractional breastfeeding proposed in this study considers that bovine milk is the most suitable food for calves in the first weeks of life; ${ }^{13}$ however, the digestive capacity increases during the firstmonths of life, according to the enzymatic profile of the digestive tract and the digestion of more complex proteins and carbohydrates becomes more efficient, stimulated by the ingestion of solid foods. ${ }^{14}$

In study analyzing Holstein calves, the fractionated breastfeeding provided greater dry matter total intake in 2 th weed before weaning and lowest cost per kilogram of total wg, indicating it is a better strategy in dairy cattle. ${ }^{15}$ Higher milk rations would reduce solid feed intake before weaning, decreasing feed intake and growth after weaning (6 Jasper and Weary, 2002). In the present research, a rapid surge in solid feed consumption by calves after wk 4 can be ascribed to gradual weaning as reported by Sweeney et al. ${ }^{7}$ In other study, increased consumption of starter and hay by calves as they aged increased intake of hay during 6th to 10th weeks resulted in higher total solid feed intake by calves fed hay compared with calves fed without forage, and likely contributed to the higher rumen $\mathrm{pH}$ observed in the calves fed hay. ${ }^{10}$ Negative effects of low rumen $\mathrm{pH}$ on intake have been observed developing calves. ${ }^{16}$ Increased solid feed consumption by young calves when forage was added to the diet was also reported by Coverdale et al. ${ }^{17}$ A previous experiment aimed to evaluate the influence of time of supply of hay in the performance of dairy calves Girolando breed submitted to early weaning at 90days of life. An alfalfa (Medicago sativa) hay was offered without any grinding. The calves received 4liters of milk daily, plus water and concentrate ad libitum. Concentrate was available from the $10^{\circ}$ day of life. A diet containing only concentrate provided similar performance to diets containing ration plus hay. However, the diet containing ration plus hay from the $15^{\circ}$ day of life provided the best ratio revenue/cost. The hay intake promoted an increase in feed conversion, reflecting a lower efficiency in the use of dietary nutrients. ${ }^{18,19}$

In the study of Khan et al. ${ }^{10}$ the sure of hay to calves fed high volumes of milk at an early age improved total solid feed intake and was beneficial for the physical development of the reticulorumen. In this research, the providing sorghum silage as forage did not compromise the performance of Girolando calves during the 2thmonth of age and could be an alternative in dairy farms that do not have hay for these animals.

\section{Conclusion}

In fractionated artificial milk feeding, providing silage and concentrate inclusions, males and females of Girolando calves presented evident differences in the performance up to 63days of life. Females showed better wg and bw at weaning and ingested more silage than male calves. Concentrate intake was significantly higher for males and could be considered a risk for rumen acidosis and diarrhea.

\section{Acknowledgements}

This study was supported by CAPES (Coordenação de 
Aperfeiçoamento de Pessoal de Nível Superior), Conselho Nacional de Desenvolvimento Científico e Tecnológico (CNPq), Fundação de Amparo à Pesquisa do Estado de Minas Gerias (FAPEMIG) and Próreitoria de Pesquisa da Universidade Federal de Minas Gerais.

\section{Conflict of interest}

The authors declare that they have no conflicts of interest.

\section{References}

1. Drackley JK. Calf nutrition from birth to breeding. Vet Clin North Am Food Anim Pract. 2008;24(1):55-86.

2. Oliveira DJC, Nogueira GP. Curvas de crecimiento de becerros de la raza Girolando. Arquivos de Ciências Veterinárias e Zoologia UNIPAR. 2006;9(1):3-8.

3. Brown EG, VandeHaar MJ, Daniels KM, et al. Effect of increasing energy and protein intake on mammary development in heifer calves. $J$ Dairy Sci. 2005;88(2):595-603.

4. Khan MA, Lee HJ, Lee WS, et al. Structural growth, rumen development, metabolic and immune response of Holstein male calves fed milk through step-down and conventional methods. J Dairy Sci. 2007;90(7):3376-3387.

5. De Paula Vieira A, Guesdon V, de Passille AM, et al. Behavioural indicators of hunger in dairy calves. Applied Animal Behaviour Science. 2008;109(2-4):180-189.

6. Jasper J, Weary DM. Effects of ad libitum milk intake on dairy calves. $J$ Dairy Sci. 2002;85(11):3054-3058.

7. Sweeney BC, Rushen J, Weary DM, de Passillé AM (2010) Duration of weaning, starter intake, and weight gain of dairy calves fed large amounts of milk. J Dairy Sci 93(1):148-52.

8. Zitnan R, Voigt J, Schönhusen U, et al. Influence of dietary concentrate to forage ratio on the development of rumen mucosa in calves. Archiv fur Tierernahrung. 1998;519(4):279-291.
9. Hill TM, Bateman HG, Aldrich JM, et al. Effects of the amount of chopped hay or cottonseed hulls in a textured calf starter on young calf performance. J Dairy Sci. 2008;91(7):2684-2693.

10. Khan MA, Weary DM, von Keyserlingk MA. Hay intake improves performance and rumen development of calves fed higher quantities of milk. J Dairy Sci. 2011;94(7):3547-3553.

11. Alvares CA, Stape JL, Sentelhas PC, et al. Köppen's climate classification map for Brazil. Meteorologische Zeitschrift. 2014;22(1):711-728.

12. Silva $\mathrm{Dj}$, Queiroz Ac. Análise de alimentos: métodos químicos e biológicos. 3rd ed. Universidade Federal de Viçosa, Viçosa; 2002. 235p.

13. Lucci C. Bovinos Leiteiros Jovens. Nobel, São Paulo, USA; 1989.

14. Orskov ER. Starch digestion and utilization in ruminants. J Anim Sci. 1986;63(5):1624-1633.

15. Le Huerou-Luron I, Guilloteau P, Wicker-Planquart C, et al. Gastric and pancreatic enzyme activities and their relationship with some gut regulatory peptides during postnatal development and weaning in calves. J Nutr. 1992;122(7):1434-1435.

16. Azevedo RA, Rufino ASR, Duarte DVL, et al. Desempenho de bezerros leiteiros em aleitamento artificial convencional ou fracionado. Revista Brasileira de Saúde e Produção Animal. 2014;15(1):237-247.

17. Suárez BJ, Van Reenen CG, Gerrits WJ, et al. Effects of supplementing concentrates differing in carbohydrate composition in veal calf diets: II. Rumen development. J Dairy Sci. 2006;89(11):4376-4386.

18. Coverdale JA, Tyler HD, Quigley JD, et al. Effect of various levels of forage and form of diet on rumen development and growth in calves. $J$ Dairy Sci. 2004;87(8):2554-2562.

19. Oliveira DP, Oliveira MVM, Vargas Júnior FM, et al. Desempenho de bezerros leiteiros lactentes alimentados com feno. Archivos de Zootecnia. 2013;62(239):357-367. 